\title{
KEMAMPUAN MENGANALISIS UNSUR INTRINSIK DAN NILAI \\ MORAL DALAM CERPEN RABIAH KARYA HASAN AL-BANNA PADA SISWA KELAS XI SMA SE-KECAMATAN BAHOROK \\ TAHUN PELAJARAN 2018/2019
}

\author{
Emi Jupio Lista Br. Sbt ${ }^{1}$, Tanita Liasna ${ }^{2}$, Sri Wahyuni ${ }^{3}$ \\ STKIP BUDIDAYA BINJAI
}

\begin{abstract}
ABSTRAK
Penelitian ini bertujuan untuk mengetahui kemampuan menganalisis unsur intrinsik dan nilai moral dalam cerpen Rabiah karya Hasan Al Banna oleh siswa kelas XI SMA seKecamatan bahorok. Metode yang digunakan adalah metode deskriptif dengan bentuk kuantitatif. Sampel penelitian ini adalah siswa kelas XI SMA se-Kecamatan Bahorok dengan jumlah 73 siswa. Adapun data yang dikumpulkan dalam penelitian ini adalah hasil dari pemahaman siswa yang berupa tes tertulis.Hasil analisis data menunjukkan bahwa kemampuan menganalisis unsur intrinsik dan nilai moral dalam cerpen Rabiah karya Hasan Al Banna pada siswa kelas XI SMA se-Kecamatan Bahorok tahun pelajaran 2018/2019 adalah baik. Hal tersebut dapat dilihat dari nilai rata-rata siswa yang telah berada pada kategori baik dengan nilai rata-rata 82,77.
\end{abstract}

Kata Kunci : unsur intrinsik, nilai moral, cerpen Rabiah

\section{PENDAHULUAN}

Pembelajaran sastra merupakan bagian yang sangat penting bagi peserta didik.Pembelajaran sastra mempunyai peranan yang relatif penting dalam mempengaruhi watak, kepribadian, memperluas wawasan kehidupan serta meningkatkan pengetahuan dan kemampuan berbahasa peserta didik.Hal ini sesuai dengan yang disampaikan oleh Fitriani (2017:1) bahwa melalui pembelajaran sastra peserta didik mampu mengenal dirinya dan budaya orang lain, serta mempunyai kemampuan imajinatif dalam dirinya untuk mengkritis dan merespon apa yang terjadi di sekitarnya.

Berdasarkan uraian tersebut, maka pembelajaran sastra yang baik harus sesuai dengan hakikat sastra dan sesuai dengan sistem sekolah.Hal ini dimaksudkan agar peserta didik dapat memiliki pengalaman sastra. Tujuan memperoleh pengalaman sastra, yaitu agar memperoleh pengetahuan sastra. Harliani mengemukakan pembelajaran sastra di sekolah mempunyai peranan penting dalam mencapai berbagai tujuan pendidikan, seperti aspek pendidikan susila, sosial, sikap, penilaiandan keagamaan.Sastra mampu mengolah watak 
pelajar, meliputi pandangan hidup atau pola pikir yang mendorong ketegasan sikap dan perilaku.

Dalam pembelajaran Bahasa Indonesia di sekolah, ada empat aspek keterampilan yang harus dikuasai peserta didik, yaitu menyimak, berbicara, membaca, dan menulis. Hal ini sesuai dengan yang disampaikan oleh Dahlianti,dkk (t.t:1) bahwa keterampilan berbahasa terdiri dari empat aspek dalam kurikulum pengajaran di sekolah. Empat aspek tersebut ialah (a) keterampilan menyimak atau mendengarkan, (b) keterampilan berbicara, (c) keterampilan membaca, dan (d) keterampilan menulis. Keempat keterampilan tersebut saling berkaitan dan saling menunjang sehingga dinamakan catur tunggal.

Keterampilan membaca adalah suatu proses yang digunakan oleh pembaca untuk memperoleh pesan yang hendak disampaikan oleh penulis melalui media kata. Tarigan menyampaikan bahwa jenis-jenis membaca antara lain ialah membaca sekilas, membaca kritis, dan membaca intensif. Membaca intensif berarti studi seksama telaah, teliti, dan penanganan terperinci yang dilaksanakan didalam kelas terhadap suatu tugas yang pendek kira-kira dua sampai empat halaman setiap hari. Membaca intensif erat kaitannya dengan kemampuan mengapresiasi suatu teks.

Kemampuan seseorang mengapresiasi dapat dipengaruhi oleh kebiasaan seseorang itu dalam membaca.Misalnya saja untuk mengapresiasi cerpen, maka kebiasaan individu dalam membaca cerpen atau karya sastra lainnya dapat memengaruhi hasil apresiasinya.Namun, membentuk kebiasaan membaca tersebut tidak diperkenalkan sejak dini.

Hakikat dari pembelajaran apresiasi sastra adalah melalui karya sastra peserta didik akan mendapatkan nilai-nilai kehidupan. Hal ini sesuai dengan yang disampaikan Rokhmansyah bahwa seorang pengarang menyampaikan pandangannya tentang kehidupan di sekitarnya melalui cerpen.Oleh sebab itu, apabila peserta didik mengapresiasi karya sastra artinya berusaha menemukan nilai-nilai kehidupan yang tercermin dalam karya sastra tersebut.

Kajian tentang cerpen sangat diperlukan untuk menunjang pembelajaran sastra di SMA.Pentingnya mempelajari teks sastra terbukti pada silabus pembelajaran yang menggunakan kurikulum 2013 (K13).Pada K13 tercantum kompetensi dasar (KD) yang berisi tentang sastra yaitu KD 3.3 yang berbunyi menganalisis teks cerita pendek, baik 
melalui lisan maupun tulisan.Salah satu submateri yang diberikan dalam pembelajaran cerpen adalah tentang analisis unsur intrinsik dan nilai moral.

Berdasarkan wawancara yang peneliti lakukan kepada guru mata pelajaran Bahasa Indonesia, peneliti mengetahui bahwa nilai siswa di SMA Negeri 1 dan SMA Pemda Langkat pada pembelajaran menganalisis unsur intrinsik dan nilai moral dalam cerpen masih di bawah KKM. Sedangkan KKM yang harus dicapai 7.0.Hal ini disebabkan oleh berbagai faktor.Pada saat observasi di kelas XI SMA Negeri 1 Bahorok, peneliti menemukan beberapa masalah menunjukkan bahwa peserta didik kurang antusias mengikuti pembelajaran menganalisis cerpen.Banyak peserta didik tidak serius mengikuti pembelajaran serta tidak berkonsentrasi. Mereka masih berbicara sendiri dengan temannya, merasa jenuh dan bosan membaca cerpen, mengantuk, melamun, dan beberapa peserta didik pandangan matannya tertuju keluar ruang kelas. Peserta didik merasa kesulitan dalam memahami isi cerpen dan mengaitkan dengan nilai moral.

Melihat realita yang terjadi, diharapkan pembelajaran menganalisis cerpen di kelas disajikan dalam situasi pembelajaran yang mampu memotivasi peserta didik, tidak membosankan, dan memudahkan peserta didik dalam menganalisis unsur intrinsik dan nilai moral.Selain itu, diharapkan pula pembelajaran terasa menyenangkan bagi peserta didik.Sehingga mampu menggali kreativitas peserta didik dalam menganalisis sebuah karya sastra.

Harus disadari, bahwa harapan-harapan tersebut tidak akan terwujud jika pembelajaran menganalisis cerpen masih berorientasi pada aspek teoretis saja. Hanya memberikan teori-teorinya saja, tidak sejalan dengan metode pengajaran menulis. Bagaimana siswa dapat menggali wawasan dan idenya bila hanya disuguhi apa itu tema, penokohan, alur, latar, dan sebagainya. Akan lebih menyenangkan jika peserta didik langsung diajak menuangkan buah pikir dan perasaan ke dalam sebuah tulisan. Dari itulah, maka dibutuhkan adanya perubahan dalam proses pembelajaran yang tidak berorientasi pada teori-teori saja

Selanjutnya, dalam penelitian ini penulis memilih cerpen karya Hasan Al-Banna yang berjudul Rabiah. Cerpen ini menceritakan tentang keberanian seorang TKW (Tenaga Kerja Wanita) yang bekerja di negara ringgit, Malaysia, dalam mempertahankan harkat dan martabatnya sebagai seorang perempuan ia diputuskan bersalah karna sudah 
membunuh seorang pria yang berusaha menodainya dan ia dihukum mati. Ia dibawa ke tiang eksekusi dan dipancung, TKW (Tenaga Kerja Wanita) yang bernama rabiah tersebut ikhlas jika dijemput maut dengan cara seperti itu. Ia mati bukan karna bunuh diri tapi karena membela diri, karena demi memperjuangkan kehormatan sebagai perempuan. Ia mati untuk hidup. Hidup adalah amanah, wajib diperjuangkan, mesti dipertanggungjawabkan. Alasan penulis memilih cerpen ini karena dalam cerpen ini terkandung nilai moral yang dapat dijadikan pembelajaran oleh peserta didik .Selain itu, kisah yang terdapat dalam cerpen ini sangat erat kaitannya dengan kondisi kehidupan masyarakat Indonesia.Sehingga sangat diharapkan stelah peserta didik menganalisis unsur intrinsik dan nilai moral cerpen tersebut dapat mengambil nilai-nilai positif yang terkandung didalamnya.

\section{METODE}

Penelitian mengenai kemampuan menganalisis unsur intrinsik dan nilai moral dalam cerpen Rabiah karya Hasan Al Banna dilaksanakan di kelas XI SMA se-Kecamatan Bahorok.Kecamatan Bahorok memiliki 2 sekolah SMA, yaitu SMA Negeri 1 Bahorok dan SMA Pemda Langkat Bahorok.

Populasi dalam penelitian ini adalah seluruh siswa kelas XI SMA se-Kecamatan Bahorok Kabupaten Langkat tahun pelajaran 2018/2019 yang berjumlah 294 orang. Sampel dalam penelitian ini ditentukan sebanyak $25 \%$ dari populasi yang ditentukan merata pada semua kelas. Pengambilan sampel dilakukan secara acak (random sampling).

Penelitian ini merupakan penelitian deskriptif kuantitatif. Variabel dalam penelitian ini adalah variabel tunggal, yaitu kemampuan menganalisis unsur intrinsik dan nilai moral dalam cerpen Rabiah karya Hasan Al Banna kelas XI SMA se-Kecamatan Bahorok Kabupaten Langkat Tahun Pelajaran 2018/ 2019. Instrumen penelitian yang digunakan dalam penelitian ini yaitu tes esai.

Untuk menganalisis data yang diperoleh penulis menempuh langkah-langkah sebagai berikut.

1. Menetapkan dan mengitung nilai akhir setiap kelompok sebagai berikut: Jumlah jawaban benar x bobot nilai

2. Mencari nilai rata-rata tiap kelompok sebagai berikut :

$$
\mathrm{M}=\frac{\text { jumlah nilai keseluruhan }}{\text { Jumlah siswa }}
$$


Menjawab pertanyaan penelitian dengan cara membandingkan nilai rata-rata dengan patokan nilai yang dikemukakan Arikunto.

\section{HASIL DAN PEMBAHASAN}

Setelah melakukan tes berupa penganalisisan unsur intrinsik dan nilai moral pada cerpen yang diperoleh dari 73 siswa, maka diperoleh hasil persentase sebagai berikut

\begin{tabular}{|c|c|c|}
\hline No & $\begin{array}{c}\text { Aspek Yang } \\
\text { Dinilai }\end{array}$ & Persentase \\
\hline 1 & Tema & $\begin{array}{c}\frac{316}{5,562} \times 100 \%=56 \\
81\end{array}$ \\
\hline 2 & Alur & $\begin{array}{c}\frac{553}{5,562} \times 100 \%=99 \\
42\end{array}$ \\
\hline 3 & $\begin{array}{l}\text { Tokoh } \\
\text { dan } \\
\text { Penokohan }\end{array}$ & $\begin{array}{c}\frac{587}{5,562} \times 100 \%= \\
105,5\end{array}$ \\
\hline 5 & $\begin{array}{l}\text { Latar / } \\
\text { Setting }\end{array}$ & $\begin{array}{c}\frac{329}{5,562} \times 100 \%=59 \\
15\end{array}$ \\
\hline 6 & $\begin{array}{l}\text { Sudut } \\
\text { Pandang }\end{array}$ & $\frac{319}{5,562} \times 100 \%=57$ \\
\hline 7 & Amanat & $\begin{array}{c}\frac{421}{5,562} \times 100 \%=75 \\
69\end{array}$ \\
\hline 8 & $\begin{array}{l}\text { Gaya } \\
\text { Bahasa }\end{array}$ & $\begin{array}{c}\frac{307}{5,562} \times 100 \%=55 \\
19\end{array}$ \\
\hline 9 & Nilai Moral & $\frac{3,620}{5,562} \times 100 \%=0,65$ \\
\hline
\end{tabular}

Dari tabel di atas terlihat jelas bahwa kemampuan siswa dalam menganalisis unsur intrinsik dan nilai moral dalam cerpen Rabiah karya Hasan Al Banna lebih tinggi pada tokoh dan penokohan yaitu $105,5 \%$. Kemampuan dalam menganalisis alur berada pada urutan kedua yaitu 99, 42\%, berlanjut dengan amanat 75, 69\%, latar/setting 59,15\%, sudut pandang $57,69 \%$, tema $56,81 \%$, gaya bahasa $55,19 \%$, diurutan terakhir adalah nilai moral yaitu $0,65 \%$. 
Kemudian, mean rata-rata kemampuan menganalisis unsur intrinsik dan nilai moral dalam cerpen Rabiah karya Hasan Al Banna oleh siswa kelas XI SMA se-Kecamatan Bahorok Tahun Pelajaran 2018/2019 dengan menggunakan rumus :

$\mathrm{M}=\frac{\text { Jumlah nilai keseluruhan }}{\text { Jumlah siswa }}$

$\mathrm{M}=\frac{6042}{73}$

$\mathrm{M}=82,77$

Berdasarkan perhitungan di atas diketahui nilai rata-rata yang diperoleh siswa kelas XI SMA se-Kecamtan Bahorok Tahun Pelajaran 2018/2019 dalam kemampuan menganalisis unsur intrinsik dan nilai moral pada cerpen adalah 82,77 . Selanjutnya peneliti akan mempersentase jumlah masing-masing siswa yang mampu menganalisis unsur intrinsik dan nilai moral pada setiap perangkat nilai. Seberapa banyak siswa yang mampu menganalisis unsur intrinsik dan nilai moral dengan katagori, baik sekali, baik, cukup dan kurang. Masing-masing akan kita persentasikan dari jumlah siswa yang termasuk dalam katagori tersebut dibagi dengan total seluruh sampel penelitian dan dikali seratus persen.

Untuk lebih jelasnya persentase siswa termasuk pada perangkat nilai kemampuan menganalisis unsur intrinsik dan nilai moral dalam cerpen Rabiah karya Hasan Al Banna oleh siswa kelas XI SMA se-Kecamatan Bahorok tahun pelajaran 2018/2019 dapat dilihat pada tabel persentase berikut ini :

\begin{tabular}{|c|l|c|l|}
\hline Angka & Kategori & $\begin{array}{c}\text { Jumlah } \\
\text { siswa }\end{array}$ & Persentase \\
\hline $90-100$ & Baik & 22 & $\begin{array}{l}22 / 73 \mathrm{x} \\
100 \% \\
30 \%\end{array}$ \\
& sekali & & $\begin{array}{l}26 / 73 \mathrm{x} \\
100 \% \\
35,7 \%\end{array}$ \\
\hline $80-89$ & Baik & 26 \\
& & & $\begin{array}{l}16 / 73 \mathrm{x} \\
100 \% \\
22 \%\end{array}$ \\
\hline $70-79$ & Cukup & 16 \\
& & 7 & $\begin{array}{l}7 / 73 \mathrm{x} \\
100 \% \\
9,5 \%\end{array}$ \\
\hline $60-69$ & Kurang & & $\begin{array}{l}2 / 73 \times 100 \% \\
=2,8 \%\end{array}$ \\
& & $\mathbf{1 0 0}$ \\
\hline$<50$ & Gagal & 2 & \multicolumn{1}{|c|}{} \\
& & &
\end{tabular}


Berdasarkan data tersebut di atas telah diketahui nilai rata-rata kemampuan menganalisis unsur intrinsik dan nilai moral dalam cerpen Rabiah karya Hasan Al Banna oleh siswa kelas XI SMA se-Kecamatan Bahorok dengan pembulatan nilai rata-rata 82,77. Setelah diperoleh nilai rata-rata yang diperoleh siswa kelas XI se-Kecamatan Bahorok tahun pelajaran 2018/2019, selanjutnya membandingkan nilai rata-rata tersebut dengan teori Suparno dan M.Yunus.

Suparno dan M.Yunus Arti tingkat penguasaan:

$$
\begin{aligned}
& 90-100 \%=\text { baik sekali } \\
& 80-89 \%=\text { baik } \\
& 70-79 \%=\text { cukup } \\
& 60-69 \%=\text { kurang } \\
& >50 \%=\text { gagal }
\end{aligned}
$$

Dengan demikian hasil penelitian ini menyatakan kemampuan menganalisis unsur intrinsik dan nilai moral dalam cerpen Rabiah karya Hasan Al Banna oleh siswa kelas XI SMA se-Kecamatan Bahorok tahun pelajaran 2018/2019 berada pada katagori baik.

\section{SIMPULAN}

Berdasarkan hasil penelitian yang disajikan di BAB IV peneliti menarik sebuah kesimpulan bahwa kemampuan menganalisis unsur intrinsik dan nilai moral dalam cerpen Rabiah karya Hasan Al Banna pada siswa kelas XI SMA se-Kecamatan Bahorok tahun pelajaran 2018/2019 dapat dikategorikan baik. Hal tersebut dapat dilihat dari nilai rata-rata siswa yaitu 82,77.

\section{DAFTAR PUSTAKA}

Al Banna, Hasan. 2011. Sampan Zulaiha. Depok: Koekoesan.

Dahlianti,dkk. t.t. Hubungan Kebiasaan Membaca Karya Sastra Deangan Kemampuan Siswa Mengapresiasi Cerpen Di SMP, Skripsi, Program Pendidikan Bahasa Indonesia, Sarjana, pontianak: FKIP Untan.

Fitriani, 2017, Kemampuan Menganalisis Unsur Intrinsik Cerita Rakyat Toraja "Baine Balo” Siswa Kelas Vlll SMPN 2 Sopai kabupaten Toraja Utara, Skripsi, Fakultas Bahasa dan Sastra, Sarjana, Makasar: Universitas Negeri Makasar.

Sugiono, 2006, Metode Penelitian Pendidikan Kuantitatif, Kualitatif, danR\&D Bandung: Alfabeta. 